\title{
Short-term changes in demersal fish assemblages exploited by an artisanal set gill net fishery in the Caribbean Sea (Colombia)
}

\section{Cambios de corto plazo en ensamblajes de peces demersales explotados por una pesquería artesanal de redes de enmalle fijas en el mar Caribe (Colombia)}

\author{
Carlos Salazar-Pérez*1, ${ }^{*}$, Eduardo Choles-Rodríguez ${ }^{1}$, Luis Manjarrés-Martínez ${ }^{1}$ \\ 1 Laboratorio de Investigaciones Pesqueras Tropicales, Universidad del Magdalena, Carrera 32, no. 22-08, \\ Santa Marta, CP 470004, Magdalena, Colombia. \\ 2 Posgrado en Ciencias del Mar y Limnología, Universidad Nacional Autónoma de México, Av. Ciudad \\ Universitaria 3000, Coyoacán, CP 04510, Mexico City, Mexico. \\ * Corresponding author. E-mail: carlos.salazar.p.95@gmail.com
}

\begin{abstract}
A basic input for implementing ecosystem-based management measures is the knowledge on fish assemblages exploited by multispecies fisheries, such as the set gill net artisanal fishery in the Gulf of Salamanca (GoS), Caribbean Sea (Colombia), which catches a large number of high-value demersal species. Assemblages of this type were identified in this study, and significant differences $(P<0.01)$ between sampling periods (2008 and 2013) and seasons were found by means of a two-way permutational multivariate analysis of variance. These results were consistent with those obtained with the principal coordinates analysis, indicating the occurrence of short-term structural changes in these assemblages. Interannual and seasonal variations in discriminant and typifying species were also identified using similarity percentages, and a decreasing trend in landing per unit effort was established by the bootstrap method. On the other hand, both the geographic location of the fishing grounds and the characterization of historical changes in the set gill nets used in the GoS were determined using the traditional ecological knowledge of local fishermen, who reported a decrease in mesh sizes. In conclusion, temporal variations could be related to changes in the gill nets, the fishing trip schedules, and the spatial distribution of fishing effort, all which occurred in response to the decrease in catch rates in traditional fishing grounds.
\end{abstract}

Key words: management, fishing gear, traditional ecological knowledge, fishing effort, PRIMER.

RESUMEN. Un insumo básico para la aplicación de medidas de manejo basado en el ecosistema es el conocimiento de los ensamblajes de especies ícticas explotados por pesquerías multiespecíficas, como la pesquería de redes de enmalle fijas del golfo de Salamanca (GdS), mar Caribe (Colombia), la cual captura un alto número de especies demersales de alto valor comercial. En el presente trabajo se identificaron tales ensamblajes, y se establecieron diferencias significativas $(P<0.01)$ entre periodos de muestreo (2008 y 2013) y épocas climáticas aplicando un análisis de varianza multivariado basado en permutaciones de 2 vías. Estos resultados fueron coherentes con los obtenidos mediante el análisis de coordenadas principales, lo que indica la ocurrencia de cambios de corto plazo en la estructura de estos ensamblajes. Mediante la técnica de porcentaje de similitud, se identificaron también variaciones interanuales y estacionales tanto en las especies tipificantes como en las discriminantes, y mediante el remuestreo (bootstrap), se estableció una tendencia decreciente en el desembarco por unidad de esfuerzo. Por otro lado, para ubicar geográficamente los sitios de pesca y caracterizar los cambios históricos en el diseño de las redes de enmalle fijas utilizadas en el GdS, se acudió al conocimiento ecológico tradicional de los pescadores rederos del área, lo que permitió detectar una disminución en los tamaños de malla empleados en esta pesquería. Por tanto, se concluye que las variaciones temporales podrían guardar relación con los cambios en las redes de enmalle, los horarios de las faenas y la distribución espacial del esfuerzo pesquero, los cuales se generaron en respuesta a la disminución en las tasas de captura obtenidas en los caladeros tradicionales.

Palabras clave: manejo, artes de pesca, conocimiento ecológico tradicional, esfuerzo pesquero, PRIMER.

\section{INTRODUCTION}

Over the last decade, the ecosystem approach to fisheries has gained increasing relevance (Shannon et al. 2010, Hutubessy et al. 2014, Defeo 2015, Biedron and Knuth 2016, Ramírez-Monsalve et al. 2016, FAO 2018). This concept is defined as "an extension of conventional fisheries management recognizing more explicitly the interdependence between human well-being and ecosystem health and the need to maintain ecosystems productivity for present and future generations" (García et al. 2003). In this context, fisheries

\section{INTRODUCCIÓN}

A lo largo de la última década ha cobrado mayor relevancia el enfoque ecosistémico de la pesca (Shannon et al. 2010, Hutubessy et al. 2014, Defeo 2015, Biedron y Knuth 2016, Ramírez-Monsalve et al. 2016, FAO 2018), el cual es definido como "una extensión de la gestión pesquera convencional que se encarga de identificar explícitamente la interdependencia entre el bienestar humano y la salud de los ecosistemas, y la necesidad de mantener la productividad de los ecosistemas para las generaciones actuales y futuras" (García et al. 2003). 
management aims to remove the potentially negative effects fishing activities may have on the structure and functioning of aquatic ecosystems (Fauconnet et al. 2015).

In the context of the ecosystem approach, it is important to understand fish assemblages that are subject to exploitation, mainly exploitation by multispecies fisheries, which is the case for most artisanal fisheries. In this study, assemblages are taken to be groups of species that maintain a phylogenetic relationship (fishes) within a given biotype (Fauth et al. 1996), without implying any interaction between them (Rochet and Trenkel 2003). With this in mind, it is clear that the use of certain non-selective and environmentally unfriendly fishing gears has contributed to changes in communities of aquatic organisms regarding their structure, behavior, and abundance (FAO 2014, Araújo et al. 2016).

This issue is particularly critical in the Gulf of Salamanca (GoS), Caribbean Sea off Colombia, where different types of artisanal fisheries operate. Of these fisheries, the most important is the set gill net fishery, which uses fishing vessels made of fiberglass (boats) or wood (dugout and canoes), with length overall between 5.0 and $7.6 \mathrm{~m}$, propelled by outboard motors or by oars and sails. This fishery uses gill nets that are made of transparent polyamide synthetic fibers and are composed of 10 to 30 panels, each with a height of 30 to 60 meshes, a length of 100 to $180 \mathrm{~m}$, and mesh sizes of $2 \frac{1}{8}$ to 10 inches (Pardo 2011). This means that this is a multispecies fishery, as it catches a large number of demersal species (Manjarrés et al. 1993, Bustos-Montes et al. 2012); therefore, changes in the composition of catches obtained with this type of fishing gear are considered valid indicators of the impact of fishing on the demersal fish communities in the study area.

Scientific fishing has been carried out in the GoS for over 4 decades (Ben-Tuvia and Ríos 1969, JICA 1981, Zúñiga and Escobar 1992, Manjarrés et al. 1993, Quintero 1993, Manjarrés 1998) for the purpose of collecting data to set abundance indices (absolute and relative) for the main commercial fish species and to characterize, from a bioecological perspective, demersal fish assemblages in the gulf (García et al.1998). However, the persistence of exploited demersal fish assemblages in this area had not been studied. Therefore, the aim of the present study was to evaluate the temporal changes in the structure of demersal fish assemblages exploited by the artisanal set gill net fishery operating in the $\mathrm{GoS}$ and to complement the results obtained from the statistical sampling carried out in the area with traditional ecological knowledge from the fishing communities that operate in the area.

\section{MATERIALS AND METHODS}

\section{Study area}

The GoS is located between $11^{\circ} 15^{\prime \prime} \mathrm{N}-74^{\circ} 15^{\prime \prime} \mathrm{W}$ (Punta Betín, Santa Marta) and $11^{\circ} 00^{\prime \prime} \mathrm{N}-74^{\circ} 50^{\prime \prime} \mathrm{W}$ (Bocas de Ceniza, mouth of Magdalena River) (Fig. 1). The continental
En este contexto, el manejo pesquero busca que la actividad pesquera no tenga un efecto potencialmente negativo sobre la estructura y la funcionalidad de los ecosistemas acuáticos (Fauconnet et al. 2015).

En un contexto ecosistémico, es de interés el conocimiento de los ensamblajes de especies ícticas que son objeto de explotación, particularmente cuando se trata de pesquerías multiespecíficas, como es el caso de la mayoría de las pesquerías artesanales. Para este estudio, se entenderá como ensamblajes a aquellos grupos de especies que mantienen una relación filogenética (peces) dentro de un biotopo determinado (Fauth et al. 1996), sin que ello signifique que existan interacciones entre ellas (Rochet y Trenkel 2003). En este orden de ideas, es claro que el uso de algunos artes de pesca no selectivos y poco amigables con el medio ambiente han contribuido a que las comunidades de organismos acuáticos presenten modificaciones en cuanto a su estructura, comportamiento y abundancia (FAO 2014, Araújo et al. 2016).

Esta situación es particularmente álgida en el golfo de Salamanca (GdS), mar Caribe frente a Colombia, donde operan diferentes tipos de pesquerías artesanales. Entre estas pesquerías destaca la de redes de enmalle fijas, la cual utiliza embarcaciones tanto de fibra de vidrio (lanchas) como de madera (cayucos y canoas), con esloras que varían de 5.0 a $7.6 \mathrm{~m}$, propulsadas por motores fuera de borda o por remos y velas. Esta pesquería usa redes de enmalle construidas de fibras sintéticas de poliamida de color transparente y constituidas por 10-30 paños, cada uno de 30 a 60 mallas de altura y de 100 a $180 \mathrm{~m}$ de longitud y con tamaños de malla de 2 $1 / 8$ a 10 pulgadas (Pardo 2011). Lo anterior hace que la pesquería sea de carácter multiespecífico, pues captura un alto número de especies demersales (Manjarrés et al. 1993, Bustos-Montes et al. 2012), razón por la que se considera que los cambios en la composición de las capturas obtenidas con este tipo de arte de pesca constituyan un indicador válido del impacto de la pesca en las comunidades de peces demersales del área de estudio.

Desde hace más de 4 décadas se ha venido realizando la pesca científica en el GdS (Ben-Tuvia y Ríos 1969, JICA 1981, Zúñiga y Escobar 1992, Manjarrés et al. 1993, Quintero 1993, Manjarrés 1998), dirigida a la recolecta de información para establecer índices de abundancia (absoluta y relativa) de las principales especies de peces comerciales y para caracterizar, desde una perspectiva bioecológica, las asociaciones de peces demersales existentes en el golfo (García et al. 1998). Sin embargo, no se habían realizado estudios que abordaran el tema de la persistencia temporal de los ensamblajes de peces demersales explotados en la zona. Por lo tanto, el presente trabajo tuvo como objetivo evaluar el cambio temporal en la estructura de los ensamblajes de peces demersales explotados por la pesquería artesanal de redes de enmalle fijas que opera en el GdS, y complementar los resultados de los muestreos estadísticos efectuados en el área con el conocimiento ecológico tradicional de las comunidades pesqueras que allí operan. 
shelf has varying widths and a maximum extension of $16 \mathrm{~km}$ (Blanco 1993). In this region there are 2 important seasons throughout the year: a dry season from mid-December to April, which is governed by northeasterly trade winds, and a rainy season from May to November, which increases runoff in rivers that drain into Ciénaga Grande de Santa Marta (García et al. 2013).

\section{Data source}

This study used landing data from the artisanal set gill net fishery, specifically data related to the fishing economic units of the Ciénaga and Puebloviejo coastal communities (Fig. 1). The data corresponded to 2 sampling periods: (1) from January to December 2008 (Duarte 2009), henceforth referred to as "first period"; and (2) from January to December 2013, when data were recorded by the Colombian Fisheries Statistical Service Information System (SEPEC, for its acronym in Spanish), henceforth referred to as "second period". Data were collected using a stratified random sampling design, considering fishing gear or fishing method as the stratification criterion. Moreover, months were used as the time strata.

Traditional ecological knowledge acquired from fishers who have traditionally used set gill nets in the study area

\section{MATERiales Y MÉTOdos}

\section{Área de estudio}

El GdS se encuentra entre $11^{\circ} 15^{\prime \prime} \mathrm{N}-74^{\circ} 15^{\prime \prime} \mathrm{W}$ (punta de Betín, Santa Marta) y $11^{\circ} 00^{\prime \prime} \mathrm{N}-74^{\circ} 50^{\prime \prime} \mathrm{W}$ (Bocas de Ceniza, desembocadura del río Magdalena) (Fig. 1). La plataforma continental presenta variaciones en su anchura y alcanza $16 \mathrm{~km}$ en su máxima extensión (Blanco 1993). En esta región se pueden distinguir 2 épocas climáticas importantes durante el año: un periodo seco desde mediados de diciembre hasta abril, regido por la acción de los vientos alisios del noreste, y un periodo de lluvias entre mayo y noviembre, durante el cual se incrementan las descargas continentales de los ríos que desembocan en la Ciénaga Grande de Santa Marta (García et al. 2013).

\section{Procedencia de los datos}

Se emplearon datos de desembarco de la pesquería artesanal de redes de enmalle fijas referidos específicamente a las unidades económicas de pesca de las comunidades pesqueras de Ciénaga y Puebloviejo (Fig. 1). Estos datos correspondieron a 2 periodos de muestreo: (1) de enero a diciembre de 2008 (Duarte 2009), en adelante referenciado como "primer

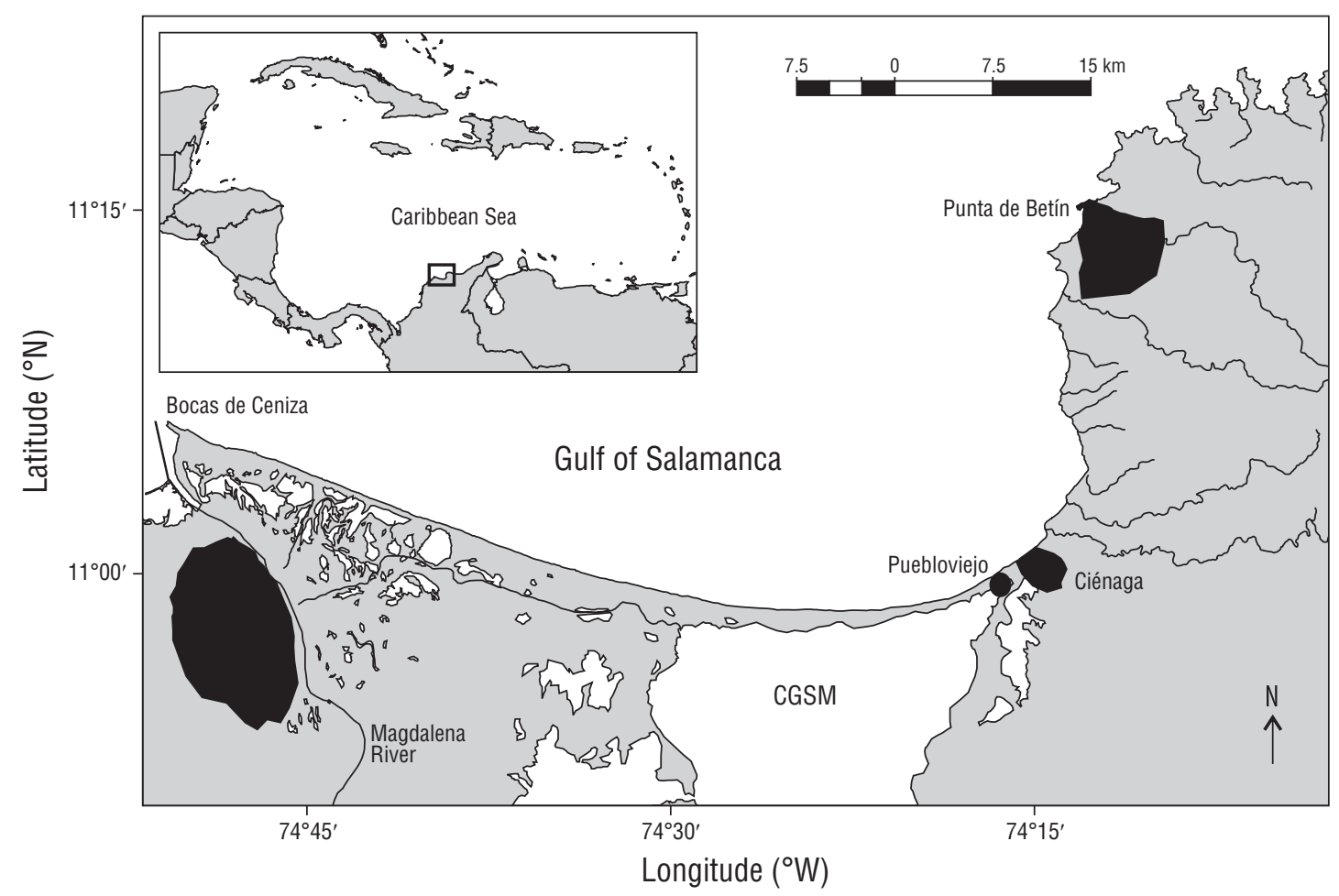

Figure 1. Geographic location of the Gulf of Salamanca (Department of Magdalena, Caribbean Sea off Colombia). CGSM: Ciénega Grande de Santa Marta.

Figura 1. Localización geográfica del golfo de Salamanca (Departamento del Magdalena, mar Caribe frente a Colombia). CGSM: Ciénega Grande de Santa Marta. 
was used to geographically reference the fishing sites reported in the SEPEC records and to characterize historical changes in the set gill net designs used in the GoS. For this, a semi-structured questionnaire was applied to 60 fishers (30 from each community), following the exponential snowball non-probability sampling method.

\section{Data treatment}

Taxa considered to be demersal were selected using Fishbase (Froese and Pauly 2017). This meant excluding taxa classified as pelagic, mesopelagic, or bathypelagic, so that the resulting assemblages would not be influenced by the occurrence of events that were markedly seasonal or showed pulsating behavior, such as catches of medium-sized pelagic species. Data were then subjected to a process of taxonomic validation and update using Fishbase (Froese and Pauly 2017) and the online version of the California Academy of Sciences' catalog of fishes (Fricke et al. 2019).

\section{Characterization of assemblages structures}

Three multivariate methods were performed using the software PRIMER-E v6 (Clarke and Warwick 2001, Clarke and Gorley 2006, Anderson et al. 2008). The methods were (1) two-way permutational analysis of variance and multivariate analysis of variance (PERMANOVA), (2) principal coordinates analysis, and (3) similarity percentage (SIMPER). Two-way PERMANOVA was used to determine if there were significant differences $(\alpha=0.05)$ between species compositions at the levels of the factor "period" (2008 and 2013) and the factor "season" (dry and rainy), with previous transformation of data with the function " $\log (\mathrm{x}+1)$ ", the use of the Bray-Curtis similarity coefficient, and the application of 999 permutations of landing samples; in addition, the method of permutation of residuals under a reduced model was used. The principal coordinates analysis was used to visualize on a three-dimensional plot the significant differences detected with PERMANOVA and thus observe the association patterns of samples at the levels of the 2 factors. The SIMPER routine was used to examine the contribution of each taxon to the average Bray-Curtis dissimilarity between the 2 sampling periods and seasons (discriminating species) and to the average similarity within each each period and season (typifying species).

\section{Determination of functional and fisheries indicators}

The weighted average of the trophic level (Rochet and Trenkel 2003) of landings was used as a functional indicator to measure the impact of the artisanal set gill net fishery on demersal fish assemblages. The trophic level of each taxon was obtained from data reported by García and Contreras (2011) and the Fishbase dataset (Froese and Pauly 2017). periodo"; y (2) de enero a diciembre de 2013, cuando los datos fueron registrados por el Sistema del Servicio Estadístico Pesquero Colombiano (SEPEC), en adelante referenciado como "segundo periodo". En ambos casos los datos fueron recolectados con base en un diseño aleatorio estratificado que utilizó como criterio de estratificación el tipo de arte o método de pesca. Además, se consideraron los meses como estratos temporales.

Para referenciar geográficamente a los sitios de pesca registrados en la plataforma del SEPEC y caracterizar los cambios históricos en el diseño de las redes de enmalle fijas utilizadas en el GdS, se acudió al conocimiento ecológico tradicional de pescadores que tradicionalmente han usado este tipo de arte en el área evaluada. Para ello, se aplicó un cuestionario semiestructurado a 60 pescadores (30 en cada comunidad), y se siguió el tipo de muestreo no probabilístico conocido como muestreo "bola de nieve", en la modalidad exponencial.

\section{Tratamiento de los datos}

Se seleccionaron los taxones considerados como demersales, de acuerdo con Fishbase (Froese y Pauly 2017). Esto implicó excluir los taxones clasificados como pelágicos, mesopelágicos o batipelágicos, de tal forma que los ensamblajes resultantes no fuesen influenciados por ocurrencia de eventos marcadamente estacionales o de comportamiento pulsante, como son las capturas de especies pelágicas medianas. Posteriormente, los datos seleccionados fueron objeto de un proceso de validación y actualización taxonómica, según Fishbase (Froese y Pauly 2017) y la versión electrónica del catálogo de peces de la California Academy of Sciences (Fricke et al. 2019).

\section{Caracterización de la estructura de los ensamblajes}

Se emplearon 3 métodos multivariados utilizando el software PRIMER-E v6 (Clarke y Warwick 2001, Clarke y Gorley 2006, Anderson et al. 2008). Estos fueron (1) análisis de varianza y análisis multivariado con base en permutaciones (PERMANOVA, por sus siglas en inglés) de 2 vías, (2) análisis de coordenadas principales y (3) análisis de porcentaje de similitud (SIMPER, por sus siglas en inglés). El PERMANOVA de 2 vías se empleó para establecer la existencia de diferencias significativas $(\alpha=0.05)$ entre las composiciones por especie de los niveles del factor "periodo" (2008 y 2013) y el factor "época climática" (seca y de lluvias), con la previa transformación de los datos mediante la función " $\log (\mathrm{x}+1)$ ", el uso del coeficiente de similitud de Bray-Curtis y la aplicación de 999 permutaciones de las muestras correspondientes a los desembarcos; además, se utilizó el método de permutación de residuos bajo un modelo reducido. El análisis de coordenadas principales estuvo dirigido a visualizar sobre 2 ejes euclidianos las diferencias significativas detectadas en el PERMANOVA y, así, observar los patrones de asociación 
Taking into account that in some cases taxa were found at the genus level, the corresponding trophic level $\left(T L_{\mathrm{Gn}}\right)$ was estimated with the following equation:

$$
T L_{\mathrm{Gn}}=\sum_{j=1}^{n} P s p_{j} \times T L_{j}
$$

where $n$ is the number of species of a genus in the landings from each period, $P s p_{j}$ is the proportion of species $j$ with respect to the annual landings of all species of that genus, and $T L j$ is the trophic level of species $j$.

To calculate the representative trophic level of the landings from each period, a weighted average formula was used, and the respective annual landings of each taxon were used as the weighting factor, that is:

$$
T L_{\mathrm{p}}=\frac{\sum_{j=1}^{k} T L_{\mathrm{j}} \times C_{j}}{\sum_{j=1}^{k} C_{j}}
$$

where $T L_{\mathrm{p}}$ is the weighted average of the trophic level in the sampling period and $C_{j}$ is the total landing of taxon $j$ in the sampling period.

Average landing per unit effort (LPUE), which was previously standardized using fishing trip duration, was used as an indicator to assess changes in the relative abundance of the main species forming the assemblages. The bias-corrected and accelerated bootstrap technique was used to create the respective confidence intervals (95\%) for this indicator (Efron and Tibshirani 1993, Haddon 2011).

\section{Assessment of fishing effort}

The Wilcoxon test $(\alpha=0.05)$ was used to determine if there were statistically significant differences between periods for the "length of gill nets", "height of gill nets", and "duration of fishing trips" variables. The likelihood ratio test $(\alpha=0.05)$ was used to evaluate the hypothesis of independence between the sampling periods and the variables "mesh size" and "fishing trip schedule". For the latter, fishing trip schedules were stratified into 3 categories: daytime (5:00 AM to 4:59 PM), "at dusk" (5:00 PM to 11:59 PM), and "at dawn" (12:00 AM to 4:59 AM). These tests were carried out using the Statgraphics Centurion v17.2 statistical software.

To evaluate the occurrence of historical changes in the spatial distribution of fishing effort by the artisanal set gill net fleet in the GoS, first the fishing area corresponding to each landing was georeferenced using a system of grids measuring one square nautical mile. For that purpose, 2 types of data were collected from the landing reports: (1) name of the coastal reference site for the fishing zone and (2) depth of fishing zone. In addition, these zones were validated with the traditional ecological knowledge of the coastal communities of the GoS. Then, for each period, the percentage distribution of fishing trips per grid was calculated. Finally, this information was mapped using the QGIS v2.18 software, stratifying the "percentage of fishing trips per grid" variable de las muestras en los niveles de los 2 factores. La rutina SIMPER se usó para examinar la contribución de cada taxón a la disimilitud promedio de Bray-Curtis entre los 2 periodos de muestreo y las épocas climáticas (especies discriminantes), y a la similitud promedio dentro de cada periodo y época climática (especies tipificantes).

\section{Determinación de indicadores funcionales y pesqueros}

Se empleó el promedio ponderado del nivel trófico (Rochet y Trenkel 2003) de los desembarcos como indicador funcional para medir el impacto de la pesquería artesanal de redes de enmalle fijas en los ensamblajes de peces demersales. El nivel trófico de cada taxón se obtuvo a partir de los datos reportados por García y Contreras (2011) y la base de datos de Fishbase (Froese y Pauly 2017).

Tomando en cuenta que en algunos casos se encontraban taxones a nivel genérico, el nivel trófico correspondiente $\left(N T_{\mathrm{Gn}}\right)$ se estimó mediante la siguiente ecuación:

$$
N T_{\mathrm{Gn}}=\sum_{j=1}^{n} P s p_{j} \times N T_{j}
$$

donde $n$ es el número de especies del género presentes en los desembarcos de cada periodo, $P s p_{j}$ es la proporción de la especie $j$ con respecto al desembarco anual de todas las especies de dicho género y $N T_{j}$ es el nivel trófico de la especie $j$.

Para el cálculo del nivel trófico representativo de los desembarcos de cada periodo, se acudió a la fórmula de la media ponderada, y se utilizaron como factor de ponderación los respectivos desembarcos anuales de cada taxon, es decir:

$$
N T_{\mathrm{p}}=\frac{\sum_{j=1}^{k} N T_{j} \times C_{j}}{\sum_{j=1}^{k} C_{j}},
$$

donde $N T_{p}$ es el promedio ponderado del nivel trófico para el periodo de muestreo y $C_{j}$ es el desembarco total del taxon $j$ en el periodo de muestreo.

Para evaluar los cambios en la abundancia relativa de las principales especies que conformaron los ensamblajes, se usó como indicador el desembarco por unidad de esfuerzo (DPUE) promedio, con la previa estandarización basada en la duración de las faenas. Para generar los respectivos intervalos de confianza $(95 \%)$ de este indicador, se aplicó la técnica de remuestreo (bootstrap) con sesgo corregido y acelerado (Efron y Tibshirani 1993, Haddon 2011).

\section{Evaluación del esfuerzo pesquero}

Para establecer la existencia de diferencias entre periodos estadísticamente significativas en las variables "longitud de las redes", "altura de las redes" y "duración de las faenas", se aplicó la prueba de Wilcoxon $(\alpha=0.05)$. Por otra parte, se utilizó la prueba de razón de verosimilitud $(\alpha=0.05)$ para evaluar la hipótesis de independencia entre los periodos de muestreo y las variables "tamaños de malla" y "horarios de faena". Para esto último, los horarios de faena se estratificaron 
into 4 categories: $<1.00 \%, 1.00 \%-3.00 \%, 3.01 \%-12.00 \%$, and $12.01 \%-17.00 \%$.

\section{RESULTS}

\section{Characterization of assemblage structures}

A total of 75 taxa were represented in the cumulative landings of the 2 sampling periods. In the landings from 2008, there were 39 taxa identified to species level and 9 to genus level, whereas landings in 2013 comprised 49 taxa identified to species level and 1 to genus level. A total of 23 taxa were common to both sampling periods.

In general, results showed marked differences in landing compositions. This was clearly evidenced by the results of the two-way PERMANOVA, which showed highly significant differences in the species composition of recorded landings per sampling period (pseudo- $F_{(1,1161)}=131.04, P<0.01$ ) and season (pseudo- $F_{(1,1161)}=9.36, P<0.01$ ). In addition, using a three-dimensional plot that explains $50.9 \%$ of the total variability, the principal coordinates analysis for the sampling period showed a clear separation pattern between landings in 2008 and landings in 2013 (Figs. 2, 3).

These differences were confirmed by the SIMPER results, which showed average dissimilarities of $87.4 \%$ and $81.7 \%$ between the 2 periods and the 2 seasons, respectively. In addition, this analysis showed higher homogeneity for landings in 2013 (average similarity of 32.7\%) with respect to landings in 2008 (average similarity of $18.4 \%$ ). Likewise, similarity was higher for landings in the dry season (average similarity of $21.2 \%$ ) in comparison with landings in the rainy season (average similarity of $19.4 \%$ ).

Additional evidence of differences between the levels of the 2 factors were derived from the analysis of typifying species for each period and season and from the analysis of discriminant species between sampling period and season. In fact, the landings from 2008 were typified by 8 species, which together contributed to $91.6 \%$ of the similarity in the landings recorded for that period. Conversely, the 2013 landings were barely typified by 2 species (Trichiurus lepturus and Micropogonias furnieri), which contributed to $93.4 \%$ of the similarity (Table 1). Likewise, for the seasons, the dry season was typified by 7 species, which contributed to $90.8 \%$ of the similarity. On the contrary, landings in the rainy season were typified by 4 species (T. lepturus, M. furnieri, Conodon nobilis, and Bagre marinus), which were responsible for $91.3 \%$ of the similarity (Table 2).

A total of 20 taxa contributed $90.6 \%$ of the average dissimilarity between the 2 periods, whereas 19 taxa were responsible for $90.3 \%$ of the average dissimilarity between seasons. The main discriminant species were T. lepturus and M. furnieri, and, in order of importance, C. nobilis, B. marinus, and Menticirrhus americanus, whose catch rates in 2013 decreased significantly with respect to 2008 (Tables 3, 4). en 3 categorías: diurnas (5:00 AM a 4:59 PM), "al anochecer" (5:00 PM a 11:59 PM) y “al amanecer” (12:00 AM a 4:59 AM). Estas pruebas se llevaron a cabo mediante el software estadístico Statgraphics Centurion v17.2.

Para evaluar la ocurrencia de cambios históricos en la distribución espacial del esfuerzo pesquero de la flota artesanal de redes de enmalle fijas en el GdS, inicialmente se georreferenció la zona de pesca correspondiente a cada desembarco, mediante un sistema de cuadriculas de una milla náutica cuadrada. Para ello, se utilizaron dos 2 tipos de datos consignados en el formato de desembarcos: (1) nombre del sitio de referencia costero de la zona de pesca y (2) profundidad de la zona de pesca. Además, estas zonas fueron validadas mediante el conocimiento ecológico tradicional de las comunidades costeras del GdS. Posteriormente, para cada periodo, se calculó la distribución porcentual de las faenas de pesca muestreadas por cuadrícula. Finalmente, esta información se mapeó mediante el software QGIS v2.18 estratificando la variable "porcentaje de faenas por cuadrícula" en 4 categorías: $<1.00 \%, 1.00 \%-3.00 \%, 3.01 \%-12.00 \% \mathrm{y}$ $12.01 \%-17.00 \%$.

\section{Resultados}

\section{Caracterización de la estructura de los ensamblajes}

Un total de 75 taxones estuvieron representados en los desembarcos acumulados de los 2 periodos de muestreo. En los desembarcos de 2008 se identificaron 39 taxones a nivel de especie y 9 a nivel de género, mientras que los desembarcos de 2013 estuvieron conformados por 49 taxones identificados a nivel de especie y 1 a nivel de género. Un total de 23 taxones fueron comunes a ambos periodos de muestreo.

En general, los resultados evidenciaron marcadas diferencias en la composición de los desembarcos. Esto fue claramente evidenciado por los resultados del PERMANOVA de 2 vías, los cuales indicaron diferencias altamente significativas en la composición por especie de los desembarcos registrados en los periodos de muestreo (pseudo- $F_{(1,1161)}=131.04$, $P<0.01$ ) y las épocas climáticas (pseudo- $F_{(1,1161)}=9.36, P<$ 0.01 ). Asimismo, con base en un gráfico tridimensional que explica el $50.9 \%$ de la variabilidad total, el análisis de coordenadas principales por periodos mostró un claro patrón de separación entre los desembarcos correspondientes a 2008 y los de 2013 (Figs. 2, 3).

Estas diferencias fueron ratificadas por los resultados del SIMPER, el cual evidenció una disimilitud promedio del $87.4 \%$ y otra del $81.7 \%$ entre los 2 periodos y las 2 épocas, respectivamente. Además, este análisis mostró una mayor homogeneidad en los desembarcos del año 2013 (similitud promedio del $32.7 \%$ ) con respecto a los desembarcos del año 2008 (similitud promedio del 18.4\%). De igual forma, se observó una mayor similitud en los desembarcos de la época seca (similitud promedio del 21.2\%) en comparación con los de la época de lluvias (similitud promedio del 19.4\%). 


\section{Determination of functional and fisheries indicators}

Trophic levels for the year $2013\left(T L_{\mathrm{p}}=4.20\right)$ increased with respect to $2008\left(T L_{\mathrm{p}}=3.90\right)$. On the other hand, for the evaluated species, significant differences were found in the average LPUE values between the 2 periods, with the exception of T. lepturus and $M$. furnieri. For the rest of the species (C. nobilis, B. marinus, M. americanus, and Umbrina coroides), the respective relative abundance indices markedly decreased (Fig. 4), and this trend was observed even when the contributions of each species to the cumulative LPUE for each period were compared (Table 5).

\section{Assessment of fishing effort}

Regarding fishing power, no statistically significant differences were observed between the 2 variables that were evaluated to characterize the sizes of the set gill nets used during the 2 study periods: length of gill net $(W=3,441.5$, $P>0.05)$ and height of gill net $(W=3,745.5, P>0.05)$. It is worth noting, however, that the length of the nets used during the second period tended to increase. On the other hand, a

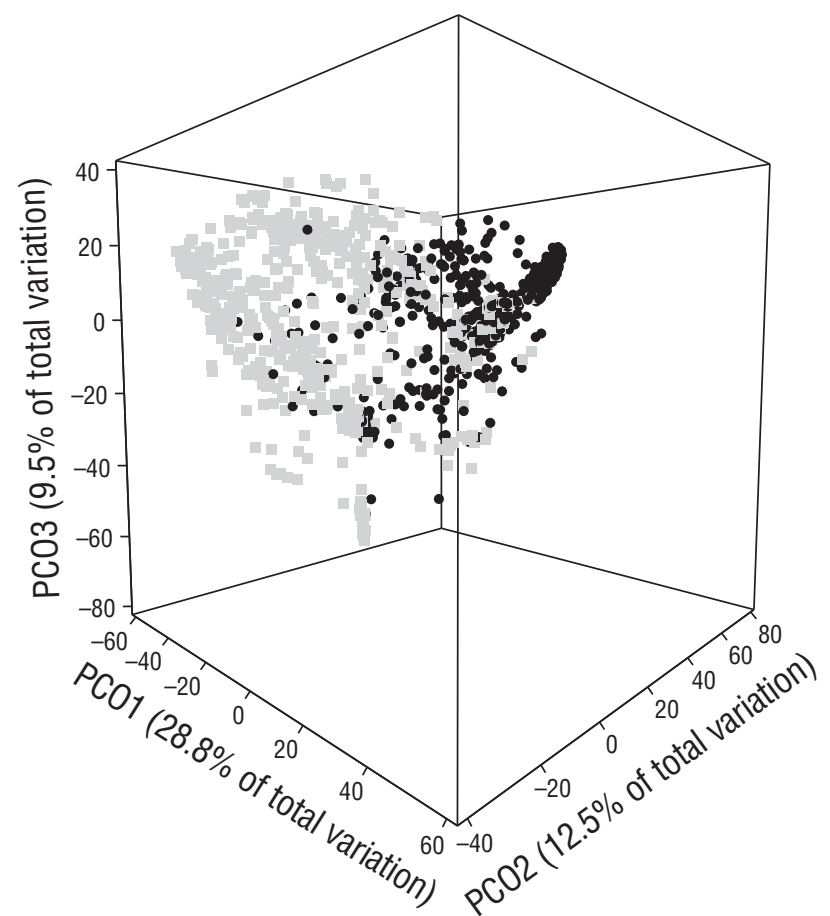

Figure 2. Principal coordinate analysis of the demersal fish assemblages recorded in the landings of each study period. The gray squares correspond to landings in the year 2008 and the black circles to landings in 2013.

Figura 2. Análisis de coordenadas principales de los ensamblajes de peces demersales registrados en los desembarcos de cada periodo de estudio. Los cuadrados grises corresponden a los desembarcos del año 2008 y los círculos negros a los de 2013.
Otras evidencias de las diferencias entre los niveles de los 2 factores fueron derivadas tanto del análisis de las especies tipificantes de cada periodo y época como del análisis de las especies discriminantes. En efecto, los desembarcos de 2008 estuvieron tipificados por 8 especies, las cuales contribuyeron al $91.6 \%$ de la similitud dentro de los desembarcos registrados en el periodo. En contraste, los desembarcos del año 2013 estuvieron apenas tipificados por 2 especies (Trichiurus lepturus y Micropogonias furnieri), las cuales contribuyeron al 93.4\% de la similitud (Tabla 1). De igual forma, en lo referente a las épocas climáticas, se resalta la tipificación de la época seca por 7 especies, las cuales contribuyeron al 90.8\% de la similitud. Por el contrario, los desembarcos de la época de lluvia fueron tipificados por 4 especies (T. lepturus, M. furnieri, Conodon nobilis y Bagre marinus), las cuales fueron responsables del $91.3 \%$ de la similitud (Tabla 2).

Un total de 20 taxones contribuyeron al $90.6 \%$ de la disimilitud promedio entre los 2 periodos, mientras que 19 taxones fueron los responsables del 90.3\% de la disimilitud promedio entre épocas climáticas. Las principales especies discriminantes fueron T. lepturus y $M$. furnieri, y, en

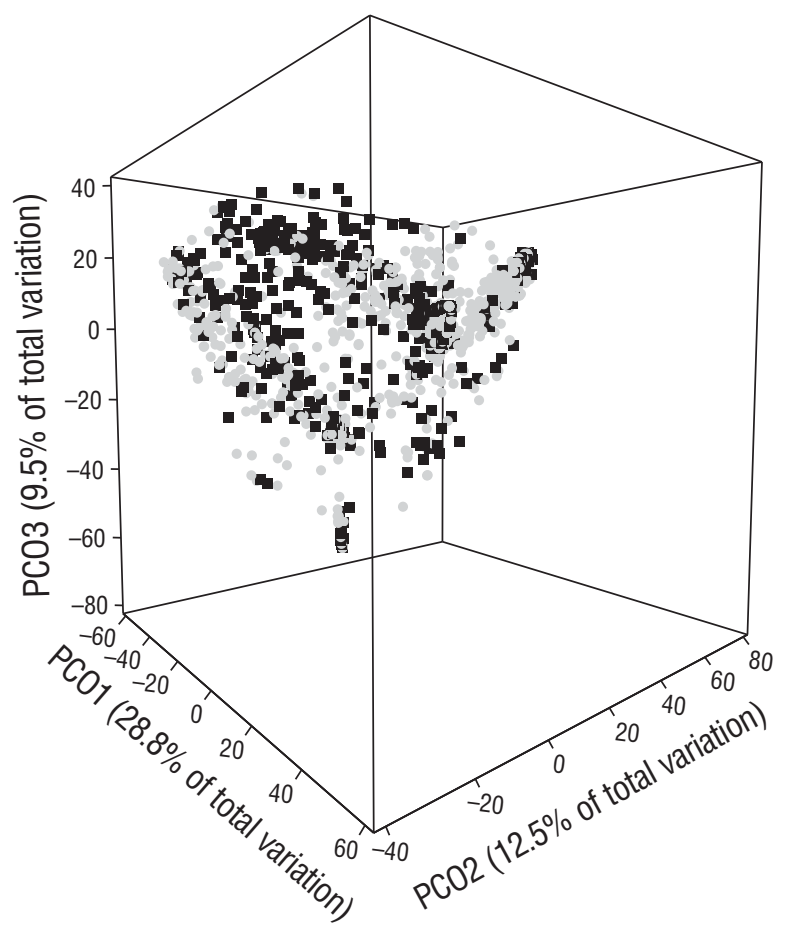

Figure 3. Principal coordinate analysis of the demersal fish assemblages recorded in the landings made in each season. The black squares correspond to landings for the dry season and the gray circles to landings for the rainy season.

Figura 3. Análisis de coordenadas principales de los ensamblajes de peces demersales registrados en los desembarcos de cada época climática. Los cuadrados negros corresponden a los desembarcos de la época seca y los círculos grises a los de la época de lluvias. 
Table 1. Mean similarity analysis of species in landings reported during the years 2008 and 2013. Only the main typifiying species for each period are shown. SD: standard deviation.

Tabla 1. Análisis de similitud promedio de las especies en los desembarcos registrados durante los años 2008 y 2013. Para cada periodo, se muestran únicamente las principales especies tipificantes. SD: desviación estándar.

\begin{tabular}{llcccc}
\hline \multirow{2}{*}{ Period } & Species & $\begin{array}{c}\text { Average } \\
\text { abundance }\end{array}$ & $\begin{array}{c}\text { Similarity } \\
\text { SD }\end{array}$ & $\begin{array}{c}\text { Contribution } \\
(\%)\end{array}$ & $\begin{array}{c}\text { Cumulative } \\
\text { contribution } \\
(\%)\end{array}$ \\
\hline 2008 & Bagre marinus & 0.68 & 0.51 & 22.76 & 22.76 \\
& Conodon nobilis & 0.62 & 0.47 & 18.40 & 41.16 \\
& Paralonchurus brasiliensis & 0.52 & 0.40 & 12.04 & 53.20 \\
& Trichiurus lepturus & 0.52 & 0.26 & 11.88 & 65.08 \\
& Micropogonias furnieri & 0.44 & 0.29 & 8.06 & 73.13 \\
& Menticirrhus americanus & 0.48 & 0.30 & 7.82 & 80.95 \\
& Umbrina coroides & 0.39 & 0.28 & 6.00 & 86.95 \\
& Lutjanus synagris & 0.28 & 0.16 & 4.59 & 91.54 \\
& & & & & \\
& Trichiurus lepturus & 1.47 & 0.86 & 75.89 & 75.89 \\
& Micropogonias furnieri & 0.64 & 0.55 & 17.51 & 93.40 \\
\hline
\end{tabular}

Table 2. Mean similarity analysis of species in reported landings by season. Only the main typifiying species for each period are shown. SD: standard deviation.

Tabla 2. Análisis de similitud promedio de las especies en los desembarcos registrados durante las épocas climáticas. Para cada época se muestran únicamente las principales especies tipificantes. SD: desviación estándar.

\begin{tabular}{llcccc}
\hline & & & & & Cumulative \\
Season & Species & $\begin{array}{c}\text { Average } \\
\text { abundance }\end{array}$ & $\begin{array}{c}\text { Similarity } \\
\text { SD }\end{array}$ & $\begin{array}{c}\text { Contribution } \\
(\%)\end{array}$ & $\begin{array}{c}\text { contribution } \\
(\%)\end{array}$ \\
\hline Dry & Trichiurus lepturus & 1.02 & 0.46 & 38.67 & 38.67 \\
& Micropogonias furnieri & 0.52 & 0.40 & 13.14 & 51.81 \\
& Conodon nobilis & 0.52 & 0.39 & 10.04 & 61.85 \\
& Bagre marinus & 0.51 & 0.40 & 9.83 & 71.68 \\
& Paralonchurus brasiliensis & 0.48 & 0.36 & 8.64 & 80.32 \\
& Umbrina coroides & 0.43 & 0.31 & 5.93 & 86.26 \\
& Menticirrhus americanus & 0.40 & 0.27 & 4.59 & 90.84 \\
& & & & & \\
Rainy & Trichiurus lepturus & 0.99 & 0.53 & 61.13 & 61.13 \\
& Micropogonias furnieri & 0.55 & 0.42 & 18.17 & 79.30 \\
& Conodon nobilis & 0.39 & 0.28 & 7.86 & 87.16 \\
& Bagre marinus & 0.28 & 0.18 & 4.10 & 91.26 \\
\hline
\end{tabular}


highly significant difference was observed in the duration of fishing trips between the 2 periods $(W=306,245.0, P<$ 0.005 ) because total duration of fishing trips increased in the second period.

Significant dependence was observed between frequencies of the different mesh sizes used in the study area and the evaluated time period $(G=13.98, P<0.05)$. During the second period the use of meshes measuring 2-3 inches increased and the use of meshes measuring 4-5, 7-8, and 9-10 inches decreased. Another significant dependence for the evaluated time period was detected for the variable "fishing trip schedule" $(G=863.4, P<0.0001)$. This interannual difference was due to the relative increase in the number of fishing trips carried out "at dusk", which was concomitant with the decrease in the number of fishing trips carried out "at dawn".

Regarding the spatial distribution of fishing effort, in 2013 the fleet shifted its fishing effort toward the southwestern zone orden de importancia, C. nobilis, B. marinus, y Menticirrhus americanus, cuyas tasas de captura en el año 2013 disminuyeron significativamente respecto al año 2008 (Tablas 3, 4).

\section{Determinación de indicadores funcionales y pesqueros}

En lo que respecta a los niveles tróficos, se evidenció un incremento en el año $2013\left(N T_{p}=4.20\right)$ con respecto al año $2008\left(N T_{p}=3.90\right)$. Por otro lado, para las especies evaluadas se encontraron diferencias significativas entre los valores de DPUE promedio para los 2 periodos, a excepción de T. lepturus y M. furnieri. Las especies restantes (C. nobilis, B. marinus, M. americanus y Umbrina coroides) experimentaron una notable disminución en sus respectivos índices de abundancia relativa (Fig. 4), y esta misma tendencia fue observada incluso cuando se compararon las contribuciones de cada especie al DPUE acumulado de cada periodo (Tabla 5).

Table 3. Mean average dissimilarity analysis of species between landings reported during the years 2008 and 2013. The main discriminating taxa are shown in decreasing order of contribution to dissimilarity. SD: standard deviation.

Tabla 3. Análisis de disimilitud promedio de las especies entre los desembarcos registrados durante los años 2008 y 2013. Se muestran las principales especies discriminantes en orden decreciente de contribución a la disimilitud. SD: desviación estándar.

\begin{tabular}{lccccc}
\hline & $\begin{array}{c}\text { Average } \\
\text { abundance } \\
\text { Taxon }\end{array}$ & $\begin{array}{c}\text { Average } \\
\text { abundance }\end{array}$ & $\begin{array}{c}\text { Dissimilarity } \\
\text { SD }\end{array}$ & $\begin{array}{c}\text { Contribution } \\
(\%)\end{array}$ & $\begin{array}{c}\text { Cumulative } \\
\text { contribution } \\
(\%)\end{array}$ \\
\hline Trichiurus lepturus & 2008 & 2013 & 1.06 & 22.43 & 22.43 \\
Micropogonias furnieri & 0.52 & 1.47 & 0.91 & 10.52 & 32.95 \\
Conodon nobilis & 0.44 & 0.64 & 0.85 & 8.67 & 41.62 \\
Bagre marinus & 0.62 & 0.26 & 0.83 & 8.42 & 50.04 \\
Paralonchurus brasiliensis & 0.68 & 0.05 & 0.69 & 5.80 & 55.84 \\
Menticirrhus americanus & 0.52 & 0.00 & 0.58 & 5.25 & 61.08 \\
Lutjanus synagris & 0.48 & 0.03 & 0.48 & 5.03 & 66.11 \\
Umbrina coroides & 0.28 & 0.09 & 0.57 & 4.31 & 70.42 \\
Cynoscion spp. & 0.39 & 0.03 & 0.44 & 2.98 & 73.40 \\
Sciades proops & 0.29 & 0.00 & 0.34 & 2.78 & 76.18 \\
Larimus breviceps & 0.00 & 0.20 & 0.49 & 2.76 & 78.94 \\
Orthopristis ruber & 0.23 & 0.06 & 0.33 & 2.65 & 81.60 \\
Cynoscion jamaicensis & 0.22 & 0.00 & 0.35 & 2.35 & 83.94 \\
Sciades spp. & 0.00 & 0.21 & 0.21 & 1.44 & 85.38 \\
Centropomus ensiferus & 0.08 & 0.00 & 0.28 & 1.16 & 86.54 \\
Cathorops mapale & 0.00 & 0.08 & 0.25 & 1.03 & 87.57 \\
Ariopsis sp. & 0.04 & 0.03 & 0.19 & 0.94 & 88.51 \\
Calamus penna & 0.00 & 0.05 & 0.20 & 0.76 & 89.27 \\
Selene vomer & 0.00 & 0.06 & 0.18 & 0.65 & 89.93 \\
Carcharhinus spp. & 0.04 & 0.01 & 0.15 & 0.65 & 90.57 \\
\hline
\end{tabular}


Table 4. Mean dissimilarity analysis of species between landings by season. The main discriminant taxa are shown in decreasing order of contribution to the dissimilarity (Diss.). SD: standard deviation.

Tabla4. Análisis de disimilitud promedio de las especies entre los desembarcos registrados por época climática. Se muestran los principales taxones discriminantes en orden decreciente de contribución a la disimilitud (Diss.). SD: desviación estándar.

\begin{tabular}{|c|c|c|c|c|c|}
\hline Taxon & $\begin{array}{c}\text { Average } \\
\text { abundance } \\
\text { Dry season }\end{array}$ & $\begin{array}{c}\text { Average } \\
\text { abundance } \\
\text { Rainy season }\end{array}$ & Diss./SD & $\begin{array}{c}\text { Cumulative } \\
\text { contribution } \\
(\%)\end{array}$ & $\begin{array}{c}\text { Cumulative } \\
\text { contribution } \\
(\%)\end{array}$ \\
\hline Trichiurus lepturus & 1.02 & 0.99 & 0.97 & 20.91 & 20.91 \\
\hline Micropogonias furnieri & 0.52 & 0.55 & 0.90 & 10.59 & 31.50 \\
\hline Conodon nobilis & 0.52 & 0.39 & 0.83 & 8.78 & 40.28 \\
\hline Bagre marinus & 0.51 & 0.28 & 0.78 & 7.90 & 48.18 \\
\hline Paralonchurus brasiliensis & 0.48 & 0.14 & 0.71 & 6.39 & 54.57 \\
\hline Menticirrhus americanus & 0.40 & 0.17 & 0.60 & 5.53 & 60.10 \\
\hline Lutjanus synagris & 0.23 & 0.16 & 0.48 & 5.36 & 65.45 \\
\hline Umbrina coroides & 0.43 & 0.09 & 0.63 & 5.21 & 70.66 \\
\hline Cynoscion spp. & 0.31 & 0.05 & 0.50 & 3.67 & 74.33 \\
\hline Larimus breviceps & 0.27 & 0.08 & 0.53 & 3.42 & 77.75 \\
\hline Sciades proops & 0.04 & 0.13 & 0.32 & 2.55 & 80.31 \\
\hline Orthopristis ruber & 0.04 & 0.14 & 0.29 & 2.29 & 82.59 \\
\hline Cynoscion jamaicensis & 0.01 & 0.16 & 0.31 & 2.00 & 84.60 \\
\hline Sciades spp. & 0.02 & 0.05 & 0.19 & 1.20 & 85.80 \\
\hline Cathorops mapale & 0.03 & 0.04 & 0.23 & 1.05 & 86.85 \\
\hline Centropomus ensiferus & 0.00 & 0.06 & 0.24 & 0.96 & 87.82 \\
\hline Ariopsis sp. & 0.02 & 0.03 & 0.19 & 0.94 & 88.75 \\
\hline Calamus penna & 0.03 & 0.03 & 0.20 & 0.88 & 89.63 \\
\hline Carcharhinus spp. & 0.02 & 0.02 & 0.15 & 0.68 & 90.32 \\
\hline
\end{tabular}

of the GoS (to the east of the mouth of the Magdalena River, in Bocas de Ceniza), contrasting that observed for 2008, when fishing trips were concentrated in areas near the fishing communities. In fact, in comparison with the trend observed for 2008, higher percentages of fishing trips were observed in the western sector of the gulf in 2013 (Fig. 5a, b). Moreover, in 2013 fishing trips were observed near Bocas de Cenizas, a sector that was not exploited in 2008.

\section{Discussion}

The multivariate and univariate analyses indicated the occurrence of short-term structural changes in the demersal fish assemblages exploited by the artisanal set gill net fishery of the GoS. For example, uniformity in assemblage structure tended to be higher in the second sampling period. Variation in the number of typifying species in each period was also reported. A total of 8 species explained $91.6 \%$ of the similarity reported for 2008, while only 2 species explained $93.4 \%$ of the similarity reported for 2013 . The historical changes in catch compositions should also be noted. Indeed, 2 studies

\section{Evaluación del esfuerzo pesquero}

En lo que respecta al poder de pesca, no se encontraron diferencias estadísticamente significativas entre las 2 variables evaluadas para caracterizar el tamaño de las redes de enmalle fijas usadas durante los 2 periodos evaluados: longitud de red $(W=3,441.5, P>0.05)$ y altura de red $(W=$ $3,745.5, P>0.05)$. Cabe destacar, sin embargo, la tendencia de aumento registrada en la longitud de las redes utilizadas durante el segundo periodo. Por otro lado, se observó una diferencia altamente significativa en la duración de las faenas entre los 2 periodos $(W=306,245.0, P<0.005)$, debido al aumento en el tiempo total de faena en el segundo periodo.

Se observó una dependencia significativa entre las frecuencias de los diferentes tamaños de malla empleados en el área de estudio y el periodo de tiempo evaluado $(G=13.98, P<$ $0.05)$. En efecto, durante el segundo periodo se registró un aumento en el uso de mallas de 2-3 pulgadas y una reducción en el uso de mallas de 4-5, 7-8 y 9-10 pulgadas. Otra dependencia significativa del periodo evaluado se detectó en el caso de la variable "horario de la faena" $(G=863.4, P<0.0001)$. 
carried out in the same zone in the mid-1990s found that these assemblages were typified by taxa from the Lutjanidae family (García et al. 1998, Manjarrés 2011), whereas in the present study the most relevant species were $B$. marinus, C. nobilis, T. lepturus, Paralonchurus brasiliensis, M. americanus, $M$. furnieri, $U$. coroides, and Lutjanus synagris (the only relevant lutjanid).

Other studies in this region (Altamar et al. 2015, Marrugo et al. 2015) also highlighted $M$. furnieri and T. lepturus as frequent species in the landings from set gill nets, and they even highlighted the predominance of immature individuals. These studies also noted the historical trend of decreasing mesh sizes, as was observed in the present study (increased use of 2-3 inch mesh sized gill nets and decreased use of 4-10 inch mesh sizes). It is worth noting that in the study region artisanal fishers tend not to modify their gill nets (specifically mesh sizes) with the seasonality of resources, given the multispecies nature of catches obtained with different mesh sizes. In fact, a previous study on the selectivity of gill nets carried out in the region (Manjarrés 1993) evidenced high species diversity in catches obtained with nets having mesh sizes of $23 / 4$ and $3 \frac{1}{2}$ inches, where only average sizes in catches varied with mesh size.

Short-term variations in demersal fish assemblages have been documented for tropical and temperate regions
Esta diferencia interanual se debió al aumento relativo en el número de faenas efectuadas "al anochecer", comportamiento que fue concomitante con la disminución de las faenas realizadas "al amanecer".

En cuanto a la distribución espacial del esfuerzo pesquero, en 2013 se evidenció un desplazamiento del esfuerzo de la flota hacia la zona suroccidental del GdS (al este de la desembocadura del río Magdalena, en Bocas de Ceniza), lo que contrasta con lo observado en 2008, cuando las faenas se concentraron en las áreas cercanas a las comunidades pesqueras. De hecho, en 2013 se observaron mayores porcentajes de faenas en el sector occidental del golfo, en comparación con la tendencia observada en 2008 (Fig. 5a, b). Además de lo anterior, en 2013 se presentaron faenas incluso en las inmediaciones de Bocas de Ceniza, un sector no explotado en 2008.

\section{Discusión}

Tanto los análisis multivariados como los univariados coinciden en la ocurrencia de cambios de corto plazo en la estructura de los ensamblajes de peces demersales explotados por la pesquería artesanal de redes de enmalle fijas del GdS. Por ejemplo, se pudo identificar la tendencia hacia una mayor uniformidad en la estructura de los ensamblajes en el
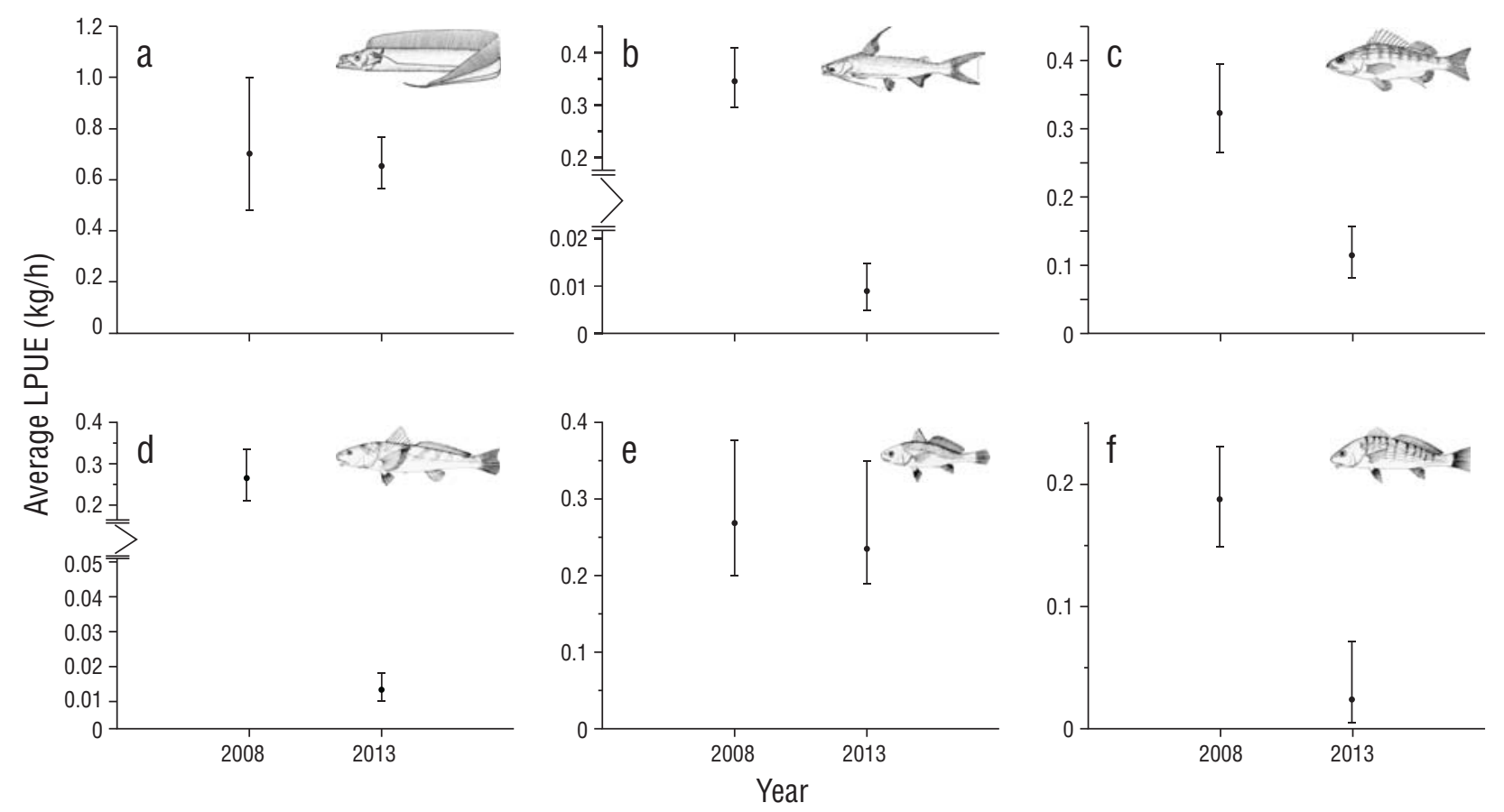

Figure 4. Temporal variation of the landing per unit effort (LPUE) of the main species caught during the 2008 period: (a) Trichiurus lepturus, (b) Marinus catfish, (c) Conodon nobilis, (d) Menticirrhus americanus, (e) Micropogonias furnieri, and (f) Umbrina coroides. The 95\% confidence intervals were established using the bias-corrected and accelerated bootstrap technique.

Figura 4. Variación temporal del desembarco por unidad de esfuerzo (LPUE) de las principales especies capturadas durante el periodo 2008: (a) Trichiurus lepturus, (b) Bagre marinus, (c) Conodon nobilis, (d) Menticirrhus americanus, (e) Micropogonias furnieri y (f) Umbrina coroides. Los intervalos de confianza del $95 \%$ se establecieron mediante la técnica bootstrap con sesgo corregido y acelerado. 
Table 5. Contribution (\%) of the different taxa to the cumulative landing per unit effort (LPUE) for each year. The 19 taxa with contributions less than $0.1 \%$ for both years are grouped as "others".

Tabla 5. Contribución (\%) de los diferentes taxones al desembarco por unidad de esfuerzo (LPUE) acumulado para cada año. Se agrupan en "otros" los 19 taxones que presentaron contribuciones menores que $0.1 \%$ en ambos años.

\begin{tabular}{|c|c|c|c|c|c|c|}
\hline Taxon & $\begin{array}{c}\text { LPUE } 2008 \\
(\mathrm{~kg} / \mathrm{h})\end{array}$ & $\%$ & $\begin{array}{l}\text { LPUE } 2013 \\
(\mathrm{~kg} / \mathrm{h})\end{array}$ & $\%$ & Grand total & $\%$ \\
\hline Trichiurus lepturus & 383.3 & 20.6 & 383.6 & 41.9 & 766.9 & 27.7 \\
\hline Conodon nobilis & 182.9 & 9.9 & 67.5 & 7.4 & 250.5 & 9.0 \\
\hline Bagre marinus & 197.1 & 10.6 & 5.4 & 0.6 & 202.5 & 7.3 \\
\hline Paralonchurus brasiliensis & 136.7 & 7.4 & 0.0 & 0.0 & 136.7 & 4.9 \\
\hline Lutjanus synagris & 123.1 & 6.6 & 11.4 & 1.2 & 134.5 & 4.9 \\
\hline Umbrina coroides & 108.6 & 5.8 & 14.8 & 1.6 & 123.4 & 4.5 \\
\hline Orthopristis ruber & 85.4 & 4.6 & 0.0 & 0.0 & 85.4 & 3.1 \\
\hline Sciades proops & 0.0 & 0.0 & 25.9 & 2.8 & 25.9 & 0.9 \\
\hline Gerres cinereus & 25.6 & 1.4 & 0.0 & 0.0 & 25.6 & 0.9 \\
\hline Mugil incilis & 2.0 & 0.1 & 23.4 & 2.6 & 25.4 & 0.9 \\
\hline Sciades spp. & 25.2 & 1.4 & 0.0 & 0.0 & 25.2 & 0.9 \\
\hline Centropomus spp. & 23.4 & 1.3 & 0.0 & 0.0 & 23.4 & 0.8 \\
\hline Carcharhinus spp. & 21.6 & 1.2 & 0.0 & 0.0 & 21.6 & 0.8 \\
\hline Mugil curema & 0.2 & 0.0 & 19.2 & 2.1 & 19.4 & 0.7 \\
\hline Centropomus ensiferus & 0.0 & 0.0 & 17.0 & 1.9 & 17.0 & 0.6 \\
\hline Lutjanus analis & 9.4 & 0.5 & 0.0 & 0.0 & 9.4 & 0.3 \\
\hline Pomadasys crocro & 0.0 & 0.0 & 9.3 & 1.0 & 9.3 & 0.3 \\
\hline Ariopsis sp. & 0.6 & 0.0 & 7.7 & 0.8 & 8.3 & 0.3 \\
\hline Albula vulpes & 4.9 & 0.3 & 2.2 & 0.2 & 7.0 & 0.3 \\
\hline Macrodon ancylodon & 6.6 & 0.4 & 0.0 & 0.0 & 6.6 & 0.2 \\
\hline Mugil liza & 1.3 & 0.1 & 5.3 & 0.6 & 6.6 & 0.2 \\
\hline Rhizoprionodon porosus & 0.0 & 0.0 & 6.4 & 0.7 & 6.4 & 0.2 \\
\hline Centropomus undecimalis & 0.0 & 0.0 & 6.1 & 0.7 & 6.1 & 0.2 \\
\hline Seriola rivoliana & 5.4 & 0.3 & 0.0 & 0.0 & 5.4 & 0.2 \\
\hline Archosargus rhomboidalis & 0.0 & 0.0 & 5.3 & 0.6 & 5.3 & 0.2 \\
\hline Hypanus guttatus & 0.0 & 0.0 & 5.1 & 0.6 & 5.1 & 0.2 \\
\hline Diapterus spp. & 4.9 & 0.3 & 0.0 & 0.0 & 4.9 & 0.2 \\
\hline
\end{tabular}


Table 5 (Cont.)

\begin{tabular}{|c|c|c|c|c|c|c|}
\hline Sphyraena picudilla & 4.6 & 0.2 & 0.0 & 0.0 & 4.6 & 0.2 \\
\hline Rhinoptera bonasus & 0.0 & 0.0 & 4.6 & 0.5 & 4.6 & 0.2 \\
\hline Sciades herzbergii & 0.0 & 0.0 & 3.8 & 0.4 & 3.8 & 0.1 \\
\hline Hypanus spp. & 3.3 & 0.2 & 0.0 & 0.0 & 3.3 & 0.1 \\
\hline Haemulopsis corvinaeformis & 2.7 & 0.1 & 0.0 & 0.0 & 2.7 & 0.1 \\
\hline Hypanus americanus & 0.0 & 0.0 & 2.7 & 0.3 & 2.7 & 0.1 \\
\hline Lobotes surinamensis & 2.3 & 0.1 & 0.4 & 0.0 & 2.7 & 0.1 \\
\hline Oligoplites spp. & 2.6 & 0.1 & 0.0 & 0.0 & 2.6 & 0.1 \\
\hline Polydactylus virginicus & 1.4 & 0.1 & 0.2 & 0.0 & 1.6 & 0.1 \\
\hline Haemulon parra & 0.0 & 0.0 & 1.3 & 0.1 & 1.3 & 0.0 \\
\hline Haemulon plumierii & 1.1 & 0.1 & 0.2 & 0.0 & 1.3 & 0.0 \\
\hline Anisotremus virginicus & 0.0 & 0.0 & 1.0 & 0.1 & 1.0 & 0.0 \\
\hline Trachinotus carolinus & 0.4 & 0.0 & 0.4 & 0.0 & 0.9 & 0.0 \\
\hline Eucinostomus melanopterus & 0.0 & 0.0 & 0.7 & 0.1 & 0.7 & 0.0 \\
\hline Priacanthus arenatus & 0.7 & 0.0 & 0.0 & 0.0 & 0.7 & 0.0 \\
\hline Amphichthys cryptocentrus & 0.0 & 0.0 & 0.6 & 0.1 & 0.6 & 0.0 \\
\hline
\end{tabular}

(Wantiez et al. 1996, Manjarrés 1998, Sousa et al. 2005, Bergastad et al. 2008, Magurran et al. 2015). For example, changes in species composition and degree of homogeneity of demersal fish assemblages occurring in a relatively short period of time were detected in relatively small geographical areas in the North Atlantic (Magurran et al. 2015). In the northern part of the Baltic Sea, regional eutrophication patterns together with fishing pressure have also caused short-term seasonal variations in species abundances, size structure, and the annual mean trophic level of fish assemblages (Mustamäki and Mattila 2015). The weighted average of the trophic level of species landed in the zone was higher in 2013 than in 2008. It is worth noting that the species that contributed the most to the structural changes seem to have similar functional characteristics as those that lost dominance in the assemblage from the second period. A similar situation has also been documented for subareas of fishing area 27 of the Food and Agriculture Organization of the United Nations (Jayasinghe et al. 2017). In addition, other studies have reported increasing values of the mean annual trophic levels of species landed in Madeira and the Azores segundo periodo de muestreo. También se registró una variación en el número de especies tipificantes en cada periodo. Mientras que un total de 8 especies explicaron el $91.6 \%$ de la similitud registrada en 2008, solo 2 especies implicaron el $93.4 \%$ de la similitud registrada en 2013. Cabe destacar también los cambios históricos evidenciados en la composición de las capturas. En efecto, 2 estudios realizados en la misma zona a mediados de la década de 1990 identificaron como tipificantes de estos ensamblajes a taxones de la familia Lutjanidae (García et al. 1998, Manjarrés 2011), en tanto que en el presente estudio las especies más relevantes fueron B. marinus, C. nobilis, T. lepturus, Paralonchurus brasiliensis, M. americanus, $M$. furnieri, U. coroides y Lutjanus synagris (único lutjánido destacado).

En otros estudios efectuados en la región (Altamar et al. 2015, Marrugo et al. 2015), M. furnieri y T. lepturus fueron destacadas también como especies frecuentes en los desembarcos con redes de enmalle fijas, e incluso se resalta la predominancia de individuos inmaduros. Estos estudios también resaltaron la tendencia histórica de la disminución en los tamaños de malla, tal como se observó en el presente estudio 
(Portugal), though the timescale was much larger than the timescale analyzed in the present study (Baeta et al. 2009, Hermida and Delgado 2016).

A decreasing trend of the average LPUE values was also recorded for the main landed species. This was the case for C. nobilis, B. marinus, M. americanus, and $U$. coroides. Decreasing catch rates appear to be related to the high levels of fishing pressure on species exploited by various types of fisheries in the zone, including the gill net fishery; for example, C. nobilis is one of the main target species of the artisanal handline fishery that operates in the zone (Manjarrés 1993). Some studies have reported that this decreasing trend in catch rates is common for resources subjected to the high levels of fishing effort exerted by artisanal fisheries and even more so when various types of fishing gear and fishing methods are used (Fariña et al. 1997, García et al. 2007). These temporal changes help explain the structural variations observed in demersal fish assemblages in the GoS.

It is worth noting that there were also short-term variations in the technological features of the set gill nets used in the GoS, with decreasing mesh sizes being the most significant trend. This sort of trend has also been reported for other fishing gears used in the region, such as cast nets and encircling gill nets (Narváez et al. 2008). The historical decrease in mesh sizes of gill nets used in GoS has also been reported (Marrugo et al. 2015). These mesh-size variations determine significant changes in the selectivity of sizes and even species and can therefore play a key role in the compositional and structural changes observed for the fish assemblages exploited with set gill nets in GoS between the 2 evaluated (aumento en el uso de redes con tamaños de malla de 2-3 pulgadas y reducción en el uso de tamaños de malla de 4-10 pulgadas). Cabe notar que en la región de estudio los pescadores artesanales no tienden a modificar sus redes de enmalle (específicamente sus tamaños de malla) en función de la estacionalidad del recurso, dado el carácter multiespecífico de las capturas obtenidas con diferentes tamaños de malla. En efecto, un estudio de selectividad de redes de enmalle realizado previamente en la región (Manjarrés 1993) evidenció una alta diversidad de especies en las capturas de redes con tamaños de malla de $23 / 4$ y $3^{1 / 2}$ pulgadas, donde únicamente variaron las tallas promedio de captura con cada tamaño de malla.

Variaciones de corto plazo en ensamblajes de peces demersales han sido documentadas tanto para regiones tropicales como para regiones templadas (Wantiez et al. 1996, Manjarrés 1998, Sousa et al. 2005, Bergstad et al. 2008, Magurran et al. 2015). Por ejemplo, en áreas geográficas relativamente pequeñas del Atlántico Norte se identificaron modificaciones tanto en la composición por especie como en el grado de homogeneidad de los ensamblajes de peces demersales en un lapso relativamente corto (Magurran et al. 2015). También en el norte del mar Báltico, los patrones regionales de eutrofización combinados con la presión pesquera ocasionaron variaciones temporales de corto plazo en la abundancia de las especies, la estructura de tallas de captura y el nivel trófico medio anual de los ensamblajes de peces (Mustamäki y Mattila 2015). El promedio ponderado del nivel trófico de las especies desembarcadas en la zona fue mayor durante el año 2013 que durante 2008. Cabe señalar que las especies

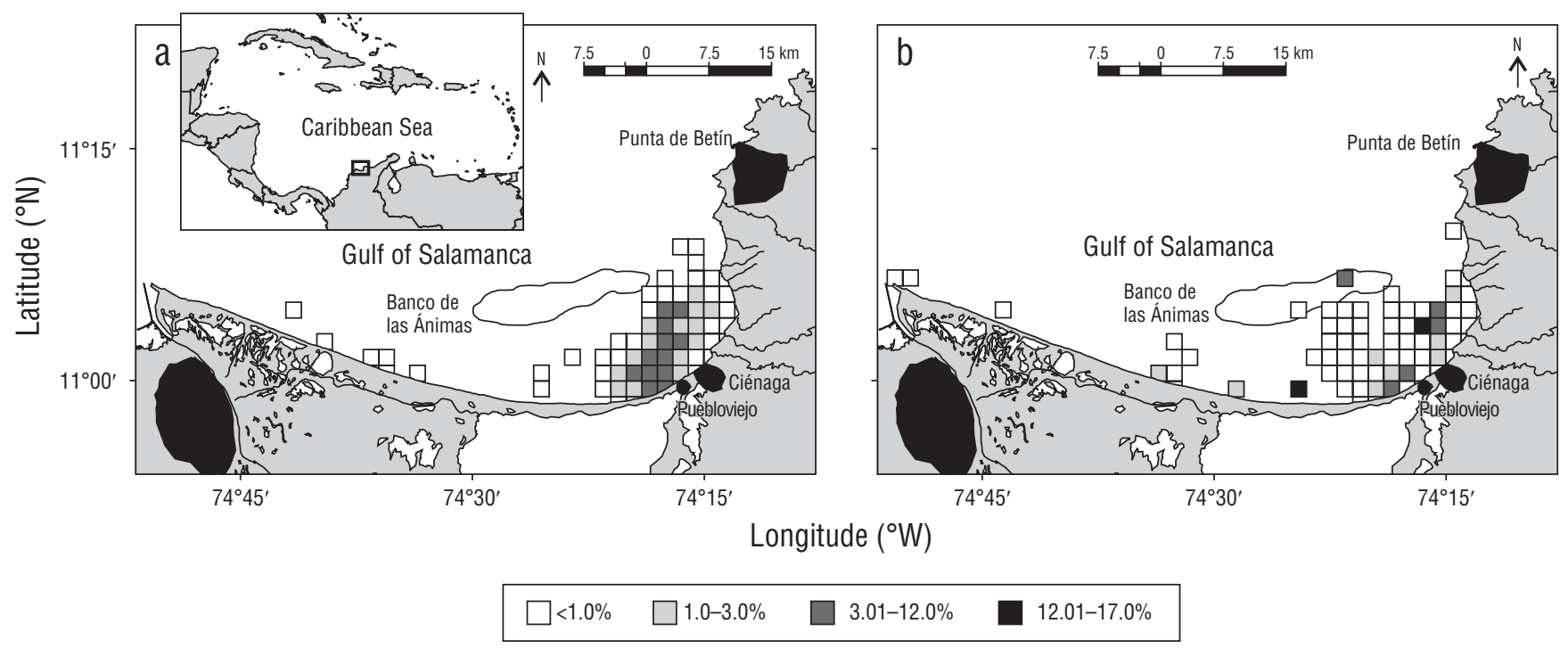

Figure 5. Historical changes in the spatial distribution of fishing effort by the artisanal set gill net fishing fleet of the Gulf of Salamanca during the 2 evaluated periods: (a) 2008 and (b) 2013. The categories for the percentage of fishing trips per grid are presented.

Figura 5. Cambios históricos en la distribución espacial del esfuerzo pesquero de la flota artesanal de la pesquería de redes de enmalle fijas del golfo de Salamanca durante los 2 periodos evaluados: (a) 2008 y (b) 2013. Se presentan las categorías de porcentaje de faenas por cuadrícula. 
periods (Karlsen and Bjarnason 1987, Sparre and Venema 1997). Moreover, these changes could be associated with the effects of other fishing gear used in GoS, such as encircling gill nets, small trawls, and beach seines, which catch a wide variety of species as bycatch (Rueda et al. 1997, Narváez et al. 2008, Manjarrés et al. 2014).

Short-term changes were also observed in the duration and schedule of fishing trips carried out by the set gill net fleet operating in GoS. We found that the duration of fishing trips tended to increase and fishing schedules shifted to dusk hours, which means fishing trips must have started at evening twilight, which for the tropical region occurs between 5:00 PM and 6:00 PM, depending on the time of year. These changes could also be affecting catch compositions if the different ethological aspects of demersal species are taken into account, such as the natural cyclic habitat migrations to feed and seek preferential refuge and breeding zones, especially in tropical environments like coral reefs or seagrass beds, where these behaviors can affect abundance, composition, heterogeneity, and trophic group structure during the twilight hours (Kruse et al. 2016).

On the spatial distribution of fishing effort, the area covered by the set gill net fleet evidently expanded toward the southwest area of the GoS. Historical changes in the spatial distribution of gill net fishing units have been referenced for the Caribbean Sea off Colombia (Marrugo et al. 2015). Another fact that should be noted was the occurrence of fishing trips near the Ánimas Bank, an area characterized by coral reef formations along the edge of the continental shelf. According to the traditional ecological knowledge of the fishers that were interviewed, variations in fishing effort were mainly associated with 3 factors: (1) the decrease in abundance of main landed species, in fact to levels of near depletion of fishing stocks for some species, such as the Atlantic tarpon (Megalops atlanticus); (2) the introduction of coal seaports in the region; and (3) the ongoing polluting actions over highly productive areas.

In conclusion, 4 factors were found to be possibly associated with the changes observed in the structure of demersal fish assemblages exploited by the artisanal set gill net fishery operating in GoS. These factors were (1) changes in the technological characteristics of gill nets, with mesh sizes tending to decrease; (2) increased fishing pressure, basically determined by increased fishing trip duration; (3) variations in fishing trip schedules; and (4) expansion of the spatial distribution of fishing effort to the southwestern area of the GoS and surrounding areas around the Ánimas Bank. The results of this research highlight the importance of conducting ecosystem-level research to support the implementation of fishery management strategies and control measures by the competent authorities, especially in areas with high fishing pressure, such as the GoS, where initiatives to implement a responsible fishing regime are still incipient. que contribuyeron en mayor grado al cambio estructural parecen tener características funcionales similares a aquellas que perdieron dominancia en el ensamblaje del segundo periodo. Una situación similar ha sido documentada también para subáreas de la zona de pesca 27 de la Organización de las Naciones Unidas para la Alimentación y la Agricultura (Jayasinghe et al. 2017). Asimismo, otros estudios reportan aumentos en los promedios anuales de los niveles tróficos de las especies en los desembarcos efectuados en Madeira y Azores (Portugal), aunque la escala temporal fue mucho mayor que la analizada en el presente estudio (Baeta et al. 2009, Hermida y Delgado 2016).

También se registró una tendencia hacia la disminución en los valores promedio del DPUE para las principales especies desembarcadas. Este fue el caso de las especies C. nobilis, B. marinus, M. americanus y U. coroides. Las disminuciones en las tasas de captura parecen estar relacionadas con los altos niveles de presión pesquera al que están sometidas algunas especies que son explotadas en la zona por varios tipos de pesquerías, incluida la de redes de enmalle; por ejemplo, C. nobilis es uno de los principales objetivos de captura de la pesquería artesanal de líneas de mano que opera en la zona (Manjarrés 1993). Algunos estudios han documentado que es común encontrar estas tendencias decrecientes en las tasas de captura de recursos sometidos a altos niveles de esfuerzo pesquero por parte de pesquerías artesanales y más aún cuando se emplean varios tipos de artes o métodos de pesca (Fariña et al. 1997, García et al. 2007). Estos cambios temporales contribuyen a explicar las variaciones observadas en la estructura de los ensamblajes de peces demersales del GdS.

Cabe notar que también se presentaron variaciones de corto plazo en las características tecnológicas de las redes de enmalle fijas utilizadas en el GdS, y la disminución en los tamaños de malla fue la tendencia más significativa. Este tipo de tendencia también ha sido documentada para otros artes de pesca usadas en la región, como la atarraya y el boliche (Narváez et al. 2008). También se han documentado disminuciones históricas en los tamaños de malla de las redes de enmalle usadas en el GdS (Marrugo et al. 2015). Estas variaciones en los tamaños de malla determinan cambios significativos en la selectividad de tallas e incluso de especies, por lo cual pueden jugar un papel determinante en los cambios observados en la composición y la estructura de los ensamblajes de peces explotados con redes de enmalle fijas en el GdS entre los 2 periodos evaluados (Karlsen y Bjarnason 1987, Sparre y Venema 1997). Asimismo, estos cambios también pueden estar relacionados con el efecto de otros tipos de arte de pesca usados en el GdS, tales como el boliche, las changas y los chinchorros de jala, los cuales capturan una amplia variedad de especies en calidad de fauna acompañante (Rueda et al. 1997, Narváez et al. 2008, Manjarrés et al. 2014).

También se observaron cambios de corto plazo en la duración y los horarios de las faenas efectuadas por las unidades 


\section{ACKNOWLEDGMENTS}

The authors thank the National Aquaculture and Fisheries Authority (AUNAP, Colombia) and the COMANEJO project for providing some of the information that helped develop the present study. We would also like to thank Felix Cuello, for his contributions and constructive criticism, the entire work group of the Tropical Fisheries Research Laboratory at the University of Magdalena, and especially the artisanal fishermen from the Ciénaga and Puebloviejo communities. There is no conflict of interest to declare for this article.

English translation by Claudia Michel-Villalobos.

\section{REFERENCIAS}

Altamar J, Manjarrés-Martínez L, Duarte LO, Cuello F, EscobarToledo F. 2015. ¿Qué tamaños deberíamos pescar? [What sizes should we fish?]. Santa Marta (Colombia): Autoridad Nacional de Acuicultura y Pesca (AUNAP)-Universidad del Magdalena. 54 p.

Anderson MJ, Gorley RN, Clarke KR. 2008. PERMANOVA+ for PRIMER: Guide to software and Statistic Methods. Plymouth (United Kingdom): PRIMER-E. 214 p.

Araújo FG, Costa-de-Azevedo MC, Penha-Guedes AP. 2016. Interdecadal changes in fish communities of a tropical bay in southeastern Brazil. Reg Stud Mar Sci. 3:107-118. https://dx.doi.org/10.1016/j.rsma.2015.06.001

Baeta F, Costa MJ, Cabral H. 2009. Changes in the trophic level of Portuguese landings and fish market price variation in the last decades. Fish Res. 97(3):216-222.

https://doi.org/10.1016/j.fishres.2009.02.006

Ben-Tuvia A, Ríos C. 1969. Investigación sobre peces y pesca exploratoria del B/I CHOCO a lo largo del Caribe Colombiano durante 1969 [Research on fish and exploratory fishing of R/V CHOCO throughout the Colombian Caribbean during 1969]: Proyecto para el Desarrollo de la Pesca Marítima en Colombia (PNUD-FAO- INDERENA). Bogotá (Colombia): INDERENA; (Divulgación Pesquera; vol. 2, No. 1). 47 p.

Bergstad OA, Menezes G, Høines AS. 2008. Demersal fish on a mid-ocean ridge: Distribution patterns and structuring factors. Deep Sea Res II. 55(1-2):185-202. https://doi.org/10.1016/j.dsr2.2007.09.005

Biedron IS, Knuth BA. 2016. Toward shared understandings of ecosystem-based fisheries management among fishery management councils and stakeholders in the U.S. Mid-Atlantic and New England regions. Mar Policy. 70:40-48. http://dx.doi.org/10.1016/j.marpol.2016.04.010

Blanco J. 1993. Reconocimiento piloto de fondos, ambiente, fauna asociada y recursos pesqueros en aguas costeras del departamento del Magdalena [Pilot recognition of seafloors, environment, associated fauna, and fishery resources in coastal waters of the departament of Magdalena]. Santa Marta (Colombia): Instituto de Investigaciones Marinas "José Benito Vives de Andreís". 223 p.

Bustos-Montes D, Cuello F, Salas S, Saza A, De la Hoz J, GrijalbaBendeck M, Posada-Peláez C, Santafé-Muñoz A, CuellarPinzón J. 2012. Variación espacio-temporal del desembarco pesquero artesanal marítimo del departamento del Magdalena, Caribe colombiano [Spatio-temporal changes of the maritime artisanal fishing landing of the departament of Magdalena, Colombian Caribbean]. In: Grijalba-Bendeck M, BustosMontes D, Posada C, Santafé-Muñez A (eds.), La pesca de pesca que emplean redes de enmalle fijas en el GdS. Se evidenció una tendencia hacia el aumento en la duración de las faenas y un desplazamiento de los horarios de pesca hacia el anochecer, lo cual implica iniciar la faena al comienzo del crepúsculo vespertino, que para la región tropical en cuestión se da entre las 5:00 PM y las 6:00 PM, según la época del año. Estos cambios también pueden tener un efecto en la composición de las capturas si se consideran aspectos de la etología de las diferentes especies demersales, como lo son la migración cíclica natural de hábitat para la obtención de alimentos y la preferencia de refugio y zonas de reproducción, en especial en ambientes tropicales como arrecifes de corales o campos de pastos marinos, donde estos comportamientos pueden afectar la abundancia, la composición, la heterogeneidad y la estructura de los grupos tróficos durante horas de crepúsculo (Kruse et al. 2016).

En lo que respecta a la distribución espacial del esfuerzo pesquero, fue evidente la ampliación del área de cobertura de la flota de redes de enmalle fijas hacia la zona suroccidental del GdS. Cambios históricos en la distribución espacial de las unidades de pesca que usan redes de enmalle han sido referenciados para el mar Caribe frente a Colombia (Marrugo et al. 2015). Otro hecho a resaltar fue la ocurrencia de faenas de pesca en las inmediaciones del banco de las Ánimas, zona que se caracteriza por las formaciones de arrecife sobre el borde de la plataforma continental. Según el conocimiento ecológico tradicional de los pescadores encuestados, estas variaciones en el esfuerzo pesquero han tenido relación principalmente con 3 factores: (1) la disminución en las abundancias de las principales especies desembarcadas, incluso prácticamente a niveles de agotamiento de las poblaciones pesqueras en el caso de algunas especies, como el sabalete (Megalops atlanticus); (2) la instalación de puertos carboníferos en la región; y (3) las reiteradas acciones de contaminación sobre zonas altamente productivas.

En conclusión, se identificaron 4 factores que podrían estar relacionados con los cambios observados en la estructura de los ensamblajes de peces demersales explotados por la pesquería artesanal de redes de enmalle fijas del GdS. Estos factores fueron los siguientes: (1) cambios en las características tecnológicas de las redes de enmalle, con una tendencia hacia la disminución en los tamaños de malla; (2) incremento de la presión pesquera, determinado básicamente por el aumento en la duración de las faenas; (3) variaciones en los horarios de las faenas; y (4) ampliación de la distribución espacial del esfuerzo pesquero hacia la zona suroccidental del GdS y las inmediaciones del banco de las Ánimas. Todo lo expuesto en esta investigación muestra la importancia de realizar investigaciones a nivel ecosistémico que sirvan de soporte para la implementación tanto de estrategias de manejo pesquero como de medidas de control por parte de las autoridades competentes, particularmente en zonas altamente presionadas por la actividad pesquera, como es el caso del GdS, donde aún son incipientes las iniciativas para implementar un régimen de pesca responsable. 
artesanal marítima del departamento del Magdalena (Colombia): una visión desde cuatro componentes [The marine artisanal fishery of the department of Magdalena (Colombia): a view from four components]. Bogotá (Colombia): Ministerio de Agricultura y Desarrollo Rural; ISBN: 978-958-725-112-8. p. 44-144.

Clarke KR, Gorley RN. 2006. PRIMER v6: Manual de usuario/ Tutorial. Plymouth (United Kingdom): PRIMER-E. 192 p.

Clarke KR, Warwick RM. 2001. Change in marine communities: An Approach to statistical Analysis and Interpretation. 2nd ed. Plymouth (United Kingdom): Plymouth Marine Lab. 172 p.

Defeo O. 2015. Enfoque ecosistémico pesquero: conceptos fundamentales y aplicación en pesquerías de pequeña escala de América Latina [Fisheries ecosystem approach: fundamental concepts and application to Latin American small-scale fisheries]. FAO documento técnico de pesca y acuicultura. Rome (Italy): Food and Agriculture Organization of the United Nations. 83 p. Paper No.: 592.

Duarte LO. 2009. Construcción participativa de una propuesta integral para la conservación de los recursos hidrobiológicos en dos áreas protegidas del Caribe de Colombia y para su uso sostenible en las zonas adyacentes [Participatory construction of an integral proposal for the conservation of hydrobiological resources in two protected areas of the Colombian Caribbean and for their sustainable use in adjacent areas]. Santa Marta (Colombia): Colciencias. 35 pp.

Efron B, Tibshirani RJ. 1993. An introduction to the Bootstrap. New York (NY): Chapman \& Hall.

[FAO] Food and Agriculture Organization of the United Nations. 2014. El estado mundial de la pesca y la Acuicultura: Oportunidades y desafíos [The state of world fisheries and aquaculture: Opportunities and challenges]. Rome (Italy): FAO. $274 \mathrm{p}$.

[FAO] Food and Agriculture Organization of the United Nations. 2018. El estado mundial de la pesca y la acuicultura: Cumplir los objetivos de desarrollo sostenible [The state of world fisheries and aquaculture: Meeting the sustainable development goals]. Rome (Italy): FAO. 233 p.

Fariña AC, Freire J, González-Gurriarán E. 1997. Demersal fish assemblages in the Galician continental shelf and upper slope (NW Spain): Spatial structure and long-term changes. Estuar Coast Shelf Sci. 44(4):435-454. https://doi.org/10.1006/ecss.1996.0148

Fauconnet L, Trenkel VM, Morandeau G, Caill-Milly N, Rochet MJ. 2015. Characterizing catches taken by different gears as a step towards evaluating fishing pressure on fish communities. Fish Res. 164:238-248. https://doi.org/10.1016/j.fishres.2014.11.019

Fauth JE, Bernardo J, Camara M, Resetarits WJ Jr, Van Buskirk J, McCollum SA. 1996. Simplifying the jargon of community ecology: A conceptual approach. Am Nat. 147(2):282-286. https://doi.org/10.1086/285850

Fricke R, Eschmeyer WN, Van der Laan R (eds.). 2019. Eschmeyer's catalog of fishes: genera, species, references. San Francisco (CA): California Academy of Sciences; updated 2020 Jan 3; accessed 2019 Jun 25. http://researcharchive.calacademy.org/ research/ichthyology/catalog/fishcatmain.asp.

Froese R, Pauly D. 2017. FishBase. World Wide Web electronic publication; [accessed 2017 Dec 2]. www.fishbase.org.

García CB, Contreras CC. 2011. Trophic levels of fish species of commercial importance in the Colombian Caribbean. Rev Biol Trop. 59(3):1195-1203.

García CB, Duarte LO, Altamar J, Manjarrés LM. 2007. Demersal fish density in the upwelling ecosystem off Colombia, Caribbean Sea: Historic Outlook. Fish Res. 85(1-2):68-73. https://doi.org/10.1016/j.fishres.2006.12.003

\section{Agradecimientos}

Los autores agradecen a la Autoridad Nacional de Acuicultura y Pesca (AUNAP, Colombia) y al proyecto COMANEJO por brindar parte de la información que dio lugar al presente estudio. Se extiende cordialmente un agradecimiento a Felix Cuello, por sus aportes y críticas constructivas, a todo el grupo de trabajo del Laboratorio de Investigaciones Pesqueras Tropicales de la Universidad del Magdalena y, especialmente, a los pescadores artesanales de las comunidades de Ciénaga y Puebloviejo. No existe conflicto de interés en el presente artículo.

García CB, Duarte LO, Ramírez G. 2013. Fisiografía y oceanografía del golfo de Salamanca (mar Caribe, Colombia) [Physiography and Oceanography of the Gulf of Salamanca (Caribbean Sea, Colombia)]. In: Melgarejo LM, García Ramírez CB (eds.), Investigación en Ciencias del Mar: Aportes de la Universidad Nacional de Colombia. Bogotá (Colombia): Universidad Nacional de Colombia, Facultad de Ciencias, Departamento de Biología, Red de Estudio del Mundo Marino. p. $111-140$.

García CB, Duarte LO, von Schiller D. 1998. Demersal fish assemblages of the Gulf of Salamanca, Colombia (southern Caribbean Sea). Mar Ecol Prog Ser. 174:13-25. https://doi.org/10.3354/meps174013

García SM, Zerbi A, Aliaume C, Do Chi T, Lasserre G. 2003. The ecosystem approach to fisheries: Issues, terminology, principles, institutional foundations, implementation and outlook. FAO Fisheries Technical Paper. Rome (Italy): Food and Agriculture Organization of the United Nations. 76 p. Paper No.: 443.

Haddon M. 2011. Modelling and Quantitative Methods in Fisheries. 2nd ed. Boca Raton (FL): CRC Press. 433 p.

Hermida M, Delgado J. 2016. High trophic level and low diversity: Would Madeira benefit from fishing down? Mar Policy. 73:130-137. https://doi.org/10.1016/j.marpol.2016.07.013

Hutubessy BG, Mosse JW, van Zwieten PAM, Hayward P. 2014. Towards an ecosystem approach to small island fisheries: A preliminary study of a balanced fishery in Kotania Bay (Seram Island, Indonesia). J Mar Isl Cult. 3(2):98-105. https://doi.org/10.1016/j.imic.2014.09.001

Jayasinghe RPPK, Amarasinghe US, Newton A. 2017. Evaluation of status of commercial fish stocks in European marine subareas using mean trophic levels of fish landings and spawning stock biomass. Ocean Coast Manage. 143:154-163. https://doi.org/10.1016/j.ocecoaman.2016.07.002

[JICA] Japan International Cooperation Agency. 1981. Informe sobre la investigación de los recursos pesqueros en la República de Colombia [Report on research of fishery resources in the Republic of Colombia]. Bogotá (Colombia): JICA. 525 p.

Karlsen L, Bjarnason BA. 1987. Small-scale fishing with driftnets. Rome (Italy): Food And Agriculture Organization Of The United Nations. 64 p. FAO Fisheries Technical Paper 284.

Kruse M, Tylor M, Muhando CA, Reuter H. 2016. Lunar, diel, and tidal changes in fish assemblages in an East African marine reserve. Reg Stud Mar Sci. 3:49-57.

https://doi.org/10.1016/j.rsma.2015.05.001

Magurran AE, Dornelas M, Moyes F, Gotelli NJ, McGill B. 2015. Rapid biotic homogenization of marine fish assemblages. Nat Commun. 6:8405. https://doi.org/10.1038/ncomms9405 
Manjarrés L. 1993. Eficiencia y selectividad de redes de enmalle en el área de Santa Marta [Efficiency and selectivity of gillnets in the Santa Marta area]. In: Manjarrés L, Correa F (eds.), Proyecto Integral de Investigaciones y Desarrollo de la Pesca Artesanal Marítima en el Área de Santa Marta [Integral Project on the Research and Development of Maritime Artisanal Fisheries in the Santa Marta Area]. Informe Técnico Final. Santa Marta (Colombia): Instituto Nacional de Pesca y Acuicultura. p. 121-144.

Manjarrés L. 1998. Caracterización ambiental, ecológica y biológico-pesquera de las asociaciones de peces demersales del Caribe colombiano norte, con énfasis en pargos (Lutjanidae) [Environmental, ecological, and biological-fishing characterization of the demersal assemblages in the northern Colombian Caribbean, with emphasis on snappers (Lutjanidae)] [MSc thesis]. Santa Marta (Colombia): Universidad Nacional de Colombia, Facultad de Biología Marina. 205 p.

Manjarrés L. 2011. Ensamblajes de peces demersales del Caribe colombiano: patrones espacio-temporales y relación con variables ambientales y pesqueras $=$ Demersal fish assemblages in the Colombian Caribbean Sea: Spatio-temporal patterns and relationships with environmental and fisheries variables [Dissertation]. Cádiz (Spain): Universidad de Cádiz. 433 p.

Manjarrés L, Infante J, Rueda A, Escorcia F. 1993. Evaluación de captura y esfuerzo pesquero en el área marítima de Santa Marta [Fishing capture and effort assessment in the maritime area of Santa Marta]. In: Manjarrés L, Correa F (eds.), Proyecto Integral de Investigaciones y Desarrollo de la Pesca Artesanal Marítima en el Área de Santa Marta [Integral Project on the Research and Development of Maritime Artisanal Fisheries in the Santa Marta Area]. Informe Técnico Final. Santa Marta (Colombia): Instituto Nacional de Pesca y Acuicultura. p. 21-43.

Manjarrés-Martínez L, Cuello F, Duarte LO, Acevedo R. 2014. Evaluación experimental del efecto de dispositivos reductores de pesca acompañante en una pesquería artesanal de arrastre camaronero del golfo de Salamanca, Caribe colombiano = Experimental assessment of the effect of bycatch reduction devices in an artisanal shrimp trawl fishery in the Gulf of Salamanca, Colombian Caribbean. Bol Invest Mar Cost. 43(2): 329-349.

Marrugo C, Altamar J, Duarte LO. 2015. Caracterización tecnológica e índices de captura de elasmobranquios, con redes de enmalle que incorporan anzuelos, utilizadas en el golfo de Salamanca (Caribe colombiano) $=$ Technological features and Elasmobranchs catch indexes with the hook-added guillnets used in the Salamanca gulf (Colombian Caribbean). Intropica. 10:84-92. http://dx.doi.org/10.21676/23897864.1650

Mustamäki N, Mattila J. 2015. Structural changes in three coastal fish assemblages in the northern Baltic Sea archipelago. Estuar Coast Shelf Sci. 164:408-417.

https://doi.org/10.1016/j.ecss.2015.07.007

Narváez-Barandica JC, Herrera-Pertuz FA, Blanco-Racedo J. 2008. Efecto de los artes de pesca sobre el tamaño de los peces en una pesquería artesanal del Caribe colombiano $=$ Effect of the fishing gears on the size of the fishes in an estuarine small-scale fishery of the Colombian Caribbean. Bol Invest Mar Cost. 37(2):163-187.

Pardo R. 2011. Efectos de las artes de pesca sobre la estructura de tallas de pargo rayado (Lutjanus synagris) en el golfo de Salamanca, Mar Caribe de Colombia [Effects of fishing gears on the size structure of the lane snapper (Lutjanus synagris) in the Gulf of Salamanca, Caribbean Sea of Colombia] [BSc thesis]. Santa Marta (Colombia): Universidad del Magdalena. 98 p.

Quintero R. 1993. Crucero evaluación de recursos demersales por el método de área barrida-fase Caribe colombiano [Cruise assessment of demersal resources by the swept area methodColombian Caribbean Phase]. Bol Cient CIOH. (13):65-74. https://doi.org/10.26640/01200542.13.65_74

Ramírez-Monsalve P, Raakjaer J, Nielsen KN, Santiago JL, Ballesteros M, Laksá U, Degnbol P. 2016. Ecosystem approach to fisheries management (EAFM) in the EU-Current sciencepolicy-society interfaces and emerging requirements. Mar Policy. 66:83-92. https://doi.org/10.1016/j.marpol.2015.12.030

Rochet MJ, Trenkel VM. 2003. Which community indicators can measure the impact of fishing? A review and proposals. Can J Fish Aquat Sci. 60(1):86-99. https://doi.org/10.1139/f02-164

Rueda ME, Mancera JE, Mendo J. 1997. Estimación del factor de retención de la red bolichera empleada en la pesquería de la Ciénaga Grande de Santa Marta, Caribe colombiano [Retention factor estimate of the bolichera net, used in fishery Cienaga Grande de Santa, Colombian Caribbean]. Rev Acad Colomb Cienc. 21(81):487-495.

Shannon LJ, Jarre AC, Petersen SL. 2010. Developing a science base for implementation of the ecosystem approach to fisheries in South Africa. Prog Oceanogr. 87(1-4):289-303. https://doi.org/10.1016/j.pocean.2010.08.005

Sousa P, Azevedo M, Gomes MC. 2005. Demersal assemblages off Portugal: Mapping, seasonal, and temporal patterns. Fish Res. 75(1-3):120-137. https://doi.org/10.1016/j.fishres.2005.03.012

Sparre P, Venema S. 1997. Introdução à avaliação de mananciais de peixes tropicais [Introduction to the assessment of tropical fish stocks]. FAO Documento Técnico Sobre as Pesca. Rome (Italy): Food and Agriculture Organization of the United Nations. Document No. 306/1. Ver 1:404 p.

Wantiez L, Harmelin-Vivien M, Kulbicki M. 1996. Spatial and temporal variation in a soft-bottom fish assemblage in St Vincent Bay, New Caledonia. Mar Biol. 125(4):801-812. https://doi.org/10.1007/BF00349263

Zúñiga H, Escobar M. 1992. Análisis de la operatividad del equipo de pesca y estimación de abundancia relativa de demersales. Zona norte del Caribe colombiano [Analysis of fishing equipment operability and estimation of relative abundance of demersal species. Northern zone of the Colombian Caribbean]. Informe complementario del crucero INPA/DEMER/9210. Santa Marta (Colombia): Universidad del Magdalena, Facultad de Ingeniería Pesquera. 27 p.

Received August 2019, accpeted January 2020. 